\title{
Biodiversity of Soil Microbes from Rhizosphere at Wamena Biological Garden (WBiG), Jayawijaya, Papua
}

\author{
SRI WIDAWATI", SULIASIH, H.J.D. LATUPAPUA, ARWAN SUGIHARTO \\ Microbiology Division, Research Center of Biology, Indonesian Institute of Sciences, Bogor 16002
}

Received: 30 November 2004. Accepted: 26 December 2004.

\begin{abstract}
The isolation, identification and population of soil microbes from rizosphere at WBiG had been done in the Soil Laboratories Microbiology, Microbiology Division, Research Center of Biology, Indonesian Institute of Sciences (LIPI), Bogor. The soil was collected randomly from 16 sites in WBiG, and taken from $0-15 \mathrm{~cm}$ depth. Isolates of microbes were identified by Bergeys manual method for bacteria; Ellis method for fungi, and the morphology of isolate method for Actinomycetes. The population of microbes was estimated by plate count method. The result of isolation, identification and population soil microbes from 16 samples in WBiG showed that 20 isolates of bacteria (Azotobacter sp., Accinetobacter sp. , Bacillus sp., Citrobacter sp., Flavobacterium sp., Klebsiella sp., Nitrosomonas sp., Pseudomonas sp., Rhizobium sp., Thiobacillus sp., Azospirillum sp., Azotobacter chrococcum, Bacillus panthothenticus, Chromobacterium violaceum, C.lividum, Escherrrichia coli, Flavobacterium breve, Klebsiella aerogenes, Spaerotillus natans, and Staphylococcus epidermidis); nine isolates of fungi (Aspergillus niger, Bisporomyces, Monilia sp., Cephalospharium sp., Verticillum sp., Giocladium sp., Penicillium sp., Nelicocephalum sp., and Cuninghamella sp.), and seven isolates of Actinomycetes (Streptomyces, Streptosporangium, Nocardia, Thermomonospora, Thermoactinomyces, Micromonospora, Mycobacterium). The population of Bacillus $\left(10^{8}-10^{9}\right)$, Rhizobium $\left(10^{6}-10^{7}\right)$, Azospirillum $\left(10^{6}-10^{7}\right)$, and Thiobacillus $\left(10^{4}-10^{9}\right)$ were founded all of soil samples.
\end{abstract}

(c) 2005 Jurusan Biologi FMIPA UNS Surakarta

Key words: soil microbes, Wamena Biological Garden (WbiG).

\section{INTRODUCTION}

Biodiversity of soil microbes has been regarded as human and vegetation life resource, especially the one connected with biological and environment resources. This can be achieved by developing a conservation system of ex-situ, like the one being pioneered by Indonesian Institute of Sciences (LIPI) in Kabupaten Jayawijaya called Wamena Biological Garden (WBiG). This is the first conservation area of ex-situ mountain biota in the Eastern part of Indonesia. It is located on Susu mountain and its surroundings with the height of $1595-1670 \mathrm{~m}$ above sea level. The temperature is $15-26^{\circ} \mathrm{C}$ with a rainfall of $1500-1900 \mathrm{~mm}$. It has a wet tropical climate with vague difference between rainy and dry seasons (SW, 2004, personal observation).

WBiG is hilly with steep and gradual slopes having various typical soil colors which make it possible for the diversity of microbes, especially in rhizosphere area. WBiG environment is still virgin and has not been touched by the cruelty of chemical fertilizers and pesticides, and is an advantage and gives a positive impact to vegetation and indigenous microbes. Especially photosphere area, it is rich in biological activities as microbes feed on the carbon compounds exuded by root. Plants may exude compounds that attack certain species to the rhizosphere that protect the root from diseases (SW, 2004, personal observation).

\footnotetext{
- Alamat korespondensi:

JI.Ir. H.Juanda 18 Bogor 16002

Tel. +62-251-324006. Fax: +62-251-325854

e-mail: widadomon@yahoo.com
}

Soil is a unity of subsistence that includes the varieties of microbes, because microbes community is one of the important components of soil, therefore, the microbial activity and species compositions are generally influenced by the physical characteristic and soil chemical properties, climate and vegetation (Jha et al., 1992).

Soil microbes are one of biota communities, which are very interesting to be studied in order to find out their existence and uses. So, soil microbes have an important role to the subsistence on earth, because it has the role on biological and chemical cycling among the flora, fauna, and life of microbes itself. Nevertheless, not every soil microbe is suitable and compatible with the habitat and its host, and it is well known that they can perform symbiotic and commensalisms. Each type of microbes fills as a unique niche and plays a different role in nutrients cycling and soil structure.

Microorganism living in the soil can be grouped into bacteria, fungi, actinomycetes, algae, and protozoa (Rao, 1994). Some groups of soil microbes are useful as biofertilizer and biocontrol. They were Klebsiella, Nitrosomonas, Thiobacillus, Lactobacillus, Azotobacter, Azospirillum, Rhizobium, Bacillus, Pseudomonas, and Frankia (one of actinomycetes group). The other actinomycetes group is Streptomyces. It is potential as a source of various bioactive compounds used in pharmaceutical industry, agriculture and for other purpose. These Streptomyces were found to have high biodiversity and can be used as source of germ plasm. The work was also done to find candidate of biopesticide from Streptomyces that can be applied together with Rhizobium and phosphate solubilizing bacteria as biofertilizer (Lestari et al., 2002). Thus the soil microbes perform a wide range of function in the ecosystem.

The aim of the research is to know the biodiversity of soil microbes from rhizosphere at WBiG. 


\section{MATERIALS AND METHODS}

The soil was collected randomly (sampling square method/stratification) from 16 sites from rhizosphere area at WBiG such as Susu mountain, Dapuk hill, Dapuk valley and near Dapuk river area. Soil sample number 1 to 11 was collected from Susu mountain area. This area was dominated by Imperata cylindrica. Whereas number 12 to 16 were collected from Koliken valley, Koliken hill and surround of Dapuk river. This area was dominated by $I$. cylindrica and seno (Castanopsis accuminattisima). The soil sample was taken from rhizosphere $(0-15 \mathrm{~cm}$ depth). There are many different color types, physical element, and soil chemistry. It founded 11 type soil samples from WBiG (Table 1. and 2.).

One $\mathrm{kg}$ soil sample from 16 sites at WBiG was kept in black plastic bags (still in fresh condition) and in the Soil Microbiological Laboratory, Microbiology Division, Research Center of Biology, Indonesian Institute of Sciences, Bogor these samples were air dried before the analysis of physic element and soil chemistry. The identification of microbes population used fresh soil. The population of microbes was determined by serial dilution plate count method (Thompson, 1989; Ravina et al., 1993). Isolation, identification, and the count of population of microbes used a selective medium, i.e. Pikovskaya, tauge agar, mannitol ashby, okon, yema congo red, DPY, PY, Na, LB, TA, etc. Identification of soil microbes was estimated by morphology, physiological test, microscopic and chemistry test.

Isolation, identification and population procedure of bacteria

Ten grams fresh soil was suspended into $90 \mathrm{ml}$ distilled water solution. Mix on wrish action shaker for one hour to provide mechanical desegregation of bacterial cell. Subsequent dilutions were prepared by manually shaking the suspension for 10 seconds to resuspend the soil. Then transfer $1 \mathrm{ml}$ an aliquot with a sterile pipette to $9 \mathrm{ml}$ sterile distilled water in a test tube. This suspension was shacked manually for 10 seconds, and subsequent serial dilutions were prepared as method as noted above $10^{-1}$ to $10^{-7}$. Spread $0.2 \mathrm{ml}$ of soil suspension from each serial dilution onto isolation selective agar medium (Pikovskaya, okon, manitol ashby, yema congo red, DPY, and PY). The number of bacteria colony was estimated after 3-7 days of incubation at $28^{\circ} \mathrm{C}$ by plate count method. Pick up the colonies to the same isolation medium, 8 strains per petridish. Select and transfer the different colonies to nutrient agar or LB (culture collection medium) or selective agar medium. The isolates of bacteria were identified by using morphological characteristic as observation of cell shape by monstaining (coccus, rod, short rod/filamentous and spore formation), gram, stain, observation of living cell (motility, spore formation, and single, paired or chain) (Krieg and Holt, 1984).

\section{Isolation, identification, and population procedure of fungi}

Ten grams soil sample was suspended onto $90 \mathrm{ml}$ of distilled water (in erlenmeyer glass), than mix on writh action shaker for one hour at $120 \mathrm{rpm}$. The soil extract was diluted from $10^{-1}$ to $10^{-7}$. Spread $0.2 \mathrm{ml}$ soil sample suspension from each serial dilution onto isolation TA medium with antibiotic. It was inoculated at $28^{\circ} \mathrm{C}$ for 3 days. Pick up the colonies to the same isolation medium. Select and transfer the different colonies to be identified by Charmichael et al. (1980), Domasch and Gans (1980), and Ellis (1993).

\section{Isolation, identification, and population procedure of actinomycetes}

Soil samples were dried at room temperature for 3 to 5 days. Then they were heated at 90 to $110^{\circ} \mathrm{C}$ for 10 to 60 minutes. The soil samples were spreaded onto isolation agar medium. They were incubated at $28^{\circ} \mathrm{C}$ for 7 to 14 days. Pick up the colonies to the same agar medium (8 colonies/petridish). The isolates were selected and transferred colonies to humic acid containing medium and YS medium. The isolation of medium for actinomycetes was humic acid-Vitamin agar medium: Humic acid $0.3 \mathrm{~g}$, $\mathrm{Na} 2 \mathrm{HPO} 40.5 \mathrm{~g}$; KCl $1.7 \mathrm{~g}$, MgSO $4.7 \mathrm{H} 2 \mathrm{O} 0.05 \mathrm{~g}$, FeSO4 $7 \mathrm{H} 2 \mathrm{O} 0.01 \mathrm{~g}, \mathrm{CaCO} 30.02 \mathrm{~g}$, B-Vitamins solution $2 \mathrm{ml}, 4 \mathrm{~N}-$ $\mathrm{NaOH} 0.6 \mathrm{ml}$, agar $18 \mathrm{~g}, \mathrm{pH}$ 7.2. Humic acid-gellan gum medium: Humic acid $0.3 \mathrm{~g}$, MOPS $1 \mathrm{~g}$, CaCL2 $0.44 \mathrm{~g}, 4 \mathrm{~N}$ $\mathrm{NaOH} 0.6 \mathrm{ml}$, trace element solution $0.5 \mathrm{ml}$, gellan gum 7 $\mathrm{g} /$ liter, $\mathrm{pH}$ 7.0. Identification of actinomycetes isolates were used morphological characteristic i.e. observation of colony (growth, color of aerial and substrate mycelium, and diffusible pigment), on ISP No. 2, ISP No. 3, ISP No. 4, and YS agar media in petridish, microscopic morphology (spore, sporangium, aerial mycelium and substrate mycelium) (Miyadoh, 2003).

\section{RESULT AND DISCUSSION}

The typical characteristics of soil and vegetation at WBiG influence soil microbes diversity, such as bacteria, fungi and actinomycetes population (table 3, 4, and 5). In an aerobe condition, bacteria dominated the area and carried out some microbiological activities in the soil because fungi and actinomycetes could not grow well without oxygen (Rao, 1994).

Physical and chemical analyses show that, in general, the soil condition at WBiG is acid with $\mathrm{pH}$ range of 4 to 6 . The soil texture is sand clay. According to Rao (1994) the soil texture depended on the percentage of sand, dust, and clay. In the case of sand clay or dust clay, its particles came together to form an aggregate. The stability of an aggregate depended on both the content of organic matter in each type of the soil (Table 1.) and the nature condition of microbes which tied the soil particles to become one. Soil texture, therefore, is important for microbes and vegetation to survive in their habitat.

Table 1. Soil physic analysis from 11 sites in Wamena Biological Garden.

\begin{tabular}{llllll}
\hline \multirow{2}{*}{$\begin{array}{l}\text { Soil } \\
\text { samples }\end{array}$} & \multirow{2}{*}{ Soil color } & & \multicolumn{2}{c}{ Vegetation } & \multicolumn{2}{c}{ Soil Texture (\%) } \\
\cline { 4 - 7 } & & & Sand & Clay & Dust \\
\hline 1 & Black & Imperata cylindrica & 18.03 & 38.06 & 43.01 \\
2 & Brown & Imperata cylindrica & 15.65 & 35.74 & 48.61 \\
3 & Gray & Imperata cylindrica & 10.89 & 38.82 & 49.28 \\
4 & Red & Imperata cylindrica & 11.51 & 65.75 & 22.69 \\
5 & Brown reddish & Imperata cylindrica & 16.36 & 43.45 & 40.19 \\
6 & Yellow & Imperata cylindrica & 17.51 & 41.42 & 41.06 \\
7 & Lime particle & Imperata cylindrica & 35.30 & 16.06 & 45.61 \\
8 & Black & Pittosporum ramiflorum & 5.79 & 51.37 & 42.84 \\
9 & Brown & Vaccinium varingiaefolium & 16.73 & 28.01 & 55.26 \\
10 & Brown & Castanopsis accuminattisima & 20.17 & 18.56 & 61.25 \\
11 & Dark brown & Grevillea papuana & 7.38 & 52.08 & 40.54 \\
\hline
\end{tabular}


Table 2. Soil chemistry analysis from 11 sites of Wamena Biological Garden.

\begin{tabular}{|c|c|c|c|c|c|c|c|}
\hline $\begin{array}{l}\text { Soil } \\
\text { samples }\end{array}$ & $\begin{array}{l}\mathbf{N} \\
(\%)\end{array}$ & $\begin{array}{c}P \\
\text { (ppm) }\end{array}$ & $\begin{array}{c}\mathrm{K} \\
(\mathrm{me} / 100 \mathrm{~g})\end{array}$ & $\begin{array}{c}\text { C } \\
(\%)\end{array}$ & $\mathrm{C} / \mathrm{N}$ & $\begin{array}{c}\mathrm{Ca} \\
(\mathrm{Me} / 100 \mathrm{~g})\end{array}$ & PH \\
\hline 1 & $\begin{array}{l}0.25 \\
(\mathrm{~m})\end{array}$ & $\begin{array}{l}2.1 \\
\text { (I) }\end{array}$ & $\begin{array}{l}0.06 \\
\text { (v.I) }\end{array}$ & $\begin{array}{c}2.76 \\
(\mathrm{~m})\end{array}$ & $\begin{array}{c}11.04 \\
(\mathrm{~m})\end{array}$ & $\begin{array}{c}32.90 \\
\text { (v.h) }\end{array}$ & $\begin{array}{l}5.26 \\
\text { (acid) }\end{array}$ \\
\hline 2 & $\begin{array}{l}0.23 \\
(\mathrm{~m})\end{array}$ & $\begin{array}{c}2.7 \\
(1)\end{array}$ & $\begin{array}{l}0.10 \\
\text { (I) }\end{array}$ & $\begin{array}{l}2.47 \\
(\mathrm{~m})\end{array}$ & $\begin{array}{c}10.74 \\
\text { (I) }\end{array}$ & $\begin{array}{c}19.23 \\
\text { (h) }\end{array}$ & $\begin{array}{l}4.25 \\
\text { (acid) }\end{array}$ \\
\hline 3 & $\begin{array}{l}0.04 \\
\text { (v.l) }\end{array}$ & $\begin{array}{l}1.6 \\
\text { (v.l) }\end{array}$ & $\begin{array}{c}0.13 \\
\text { (I) }\end{array}$ & $\begin{array}{l}0.36 \\
\text { (v.I) }\end{array}$ & $\begin{array}{l}9.00 \\
\text { (I) }\end{array}$ & $\begin{array}{l}9.73 \\
(\mathrm{~m})\end{array}$ & $\begin{array}{l}4.60 \\
\text { (acid) }\end{array}$ \\
\hline 4 & $\begin{array}{l}0.06 \\
\text { (v.l) }\end{array}$ & $\begin{array}{l}0.3 \\
\text { (v.l) }\end{array}$ & $\begin{array}{l}0.07 \\
\text { (v.l) }\end{array}$ & $\begin{array}{l}0.62 \\
\text { (v.I) }\end{array}$ & $\begin{array}{c}10.33 \\
\text { (I) }\end{array}$ & $\begin{array}{c}9.55 \\
\text { (m) }\end{array}$ & $\begin{array}{l}6.05 \\
\text { (acid) }\end{array}$ \\
\hline 5 & $\begin{array}{l}0.06 \\
\text { (v.I) }\end{array}$ & $\begin{array}{l}0.2 \\
(v . I)\end{array}$ & $\begin{array}{l}0.07 \\
\text { (v.l) }\end{array}$ & $\begin{array}{l}0.69 \\
\text { (v.I) }\end{array}$ & $\begin{array}{c}11.50 \\
(\mathrm{~m})\end{array}$ & $\begin{array}{c}8.88 \\
(\mathrm{~m})\end{array}$ & $\begin{array}{l}5.00 \\
\text { (acid) }\end{array}$ \\
\hline 6 & $\begin{array}{l}0.05 \\
\text { (v.I) }\end{array}$ & $\begin{array}{l}0.4 \\
\text { (v.l) }\end{array}$ & $\begin{array}{l}0.05 \\
\text { (v.l) }\end{array}$ & $\begin{array}{c}0.51 \\
\text { (I) }\end{array}$ & $\begin{array}{c}10.20 \\
\text { (I) }\end{array}$ & $\begin{array}{c}9.34 \\
\text { (m) }\end{array}$ & $\begin{array}{l}5.25 \\
\text { (acid) }\end{array}$ \\
\hline 7 & $\begin{array}{l}0.03 \\
\text { (v.l) }\end{array}$ & $\begin{array}{l}0.1 \\
(v . I)\end{array}$ & $\begin{array}{l}0.05 \\
\text { (v.l) }\end{array}$ & $\begin{array}{l}0.36 \\
\text { (v.l) }\end{array}$ & $\begin{array}{c}12.00 \\
(\mathrm{~m})\end{array}$ & $\begin{array}{l}9.03 \\
(\mathrm{~m})\end{array}$ & $\begin{array}{l}4.65 \\
\text { (acid) }\end{array}$ \\
\hline 8 & $\begin{array}{l}0.21 \\
(\mathrm{~m})\end{array}$ & $\begin{array}{l}4.8 \\
(\mathrm{I})\end{array}$ & $\begin{array}{l}0.53 \\
\text { (m) }\end{array}$ & $\begin{array}{c}2.54 \\
(\mathrm{~m})\end{array}$ & $\begin{array}{c}12.10 \\
(\mathrm{~m})\end{array}$ & $\begin{array}{c}26.00 \\
\text { (v.h) }\end{array}$ & $\begin{array}{l}5.30 \\
\text { (acid) }\end{array}$ \\
\hline 9 & $\begin{array}{c}0.23 \\
(\mathrm{~m})\end{array}$ & $\begin{array}{c}3.3 \\
\text { (I) }\end{array}$ & $\begin{array}{c}0.26 \\
\text { (I) }\end{array}$ & $\begin{array}{c}3.85 \\
(\mathrm{~m})\end{array}$ & $\begin{array}{c}16.74 \\
\text { (h) }\end{array}$ & $\begin{array}{c}8.82 \\
(\mathrm{~m})\end{array}$ & $\begin{array}{l}4.90 \\
\text { (acid) }\end{array}$ \\
\hline 10 & $\begin{array}{c}0.22 \\
(\mathrm{~m})\end{array}$ & $\begin{array}{l}1.6 \\
\text { (v.l) }\end{array}$ & $\begin{array}{l}0.15 \\
\text { (I) }\end{array}$ & $\begin{array}{c}3.12 \\
\text { (h) }\end{array}$ & $\begin{array}{c}14.48 \\
(\mathrm{~m})\end{array}$ & $\begin{array}{l}9.34 \\
(\mathrm{~m})\end{array}$ & $\begin{array}{l}4.35 \\
\text { (acid) }\end{array}$ \\
\hline 11 & $\begin{array}{l}0.30 \\
(\mathrm{~m})\end{array}$ & $\begin{array}{l}3.9 \\
(I)\end{array}$ & $\begin{array}{c}0.36 \\
\text { (I) }\end{array}$ & $\begin{array}{c}3.05 \\
\text { (h) }\end{array}$ & $\begin{array}{c}10.17 \\
\text { (I) }\end{array}$ & $\begin{array}{c}19.23 \\
\text { (h) }\end{array}$ & $\begin{array}{l}4.80 \\
\text { (acid) }\end{array}$ \\
\hline
\end{tabular}

Annotation: $\mathrm{v} . \mathrm{I}=$ very low $\mathrm{I}=\mathrm{low} ; \mathrm{m}=$ moderate; $\mathrm{h}=$ high; $\mathrm{v} \cdot \mathrm{h}=$ very high

The acidity level in soil sample No. 4 with $I$. cylindrica in it approached normal $\mathrm{pH}$ (6.05) followed by element contents of $\mathrm{N}, \mathrm{P}, \mathrm{K}, \mathrm{C}, \mathrm{C} / \mathrm{N}$ ratio with a low to moderate $\mathrm{Ca}$ content, and also did the other soil samples. This shows that most WBiG area is not fertile. This condition occurs because the agriculture pattern of the people around WBiG is still very simple and inherently dependent on natural soil fertility, because rotation system has been being practiced continuously for a long time, it decreases the soil fertility. Another possibility is that the people of Wamena never use chemical fertilizers.

It turned out that the physical and chemical conditions of the soil did not prevent the existence of microbes in the rhizosphere (Table 3, 4, 5). Those tables illustrate the results of microbes identification which go as follows: Twenty isolates of bacteria (genus and species), nine isolates of fungi (genus and species) and seven isolates of actinomycetes (genus). All these isolates were gotten from soil samples taken from the depth of $0-15 \mathrm{~cm}$ under rhizosphere plants. Thus, soil acidity, soil fertility, soil texture, vegetation types and perhaps the elevation of area and soil colors (Figure 1.) can influence the variety and population of microbes in a rhizosphere. Widawati and Suliasih (2001) noted, the number of microbes at Halimun mountain was influenced by the different vegetation type, soil $\mathrm{pH}$, and the elevation of area. The composition of population and soil microbes activity were influenced by the different climate and vegetation (Jha et al., 1992). On the other hand the activity of microorganisms is constantly changing with temperature, moisture, $\mathrm{pH}$, food supply and other environmental conditions. So, different species prefer different condition. So, microbes are generally assumed that of the major microbial group's soil, fungi are tolerant of acidity, whereas most bacteria and actinomycetes are relative in tolerant (Gunarto, 2000).

The microbes population in the out area of rhizosphere was not as numerous as that in the rhizosphere. This can be seen in soil sample No. 7 (Table3) which contained limestone. There might have been no association connection between microbes and local vegetation that the existence of microbes in the soil is not good. When, an association occurs between vegetation and microbes, plant root exudates macro and micro element to release it into the soil rhizosphere to create a new environment (niche) for the growth of microorganism (Setiadi, 1989). Looking at the number of population in the sample taking area Nos. 1, 4, 6, 11,12 , and 15 it was supposed that association connection between vegetation and microbes had taken place. Therefore, each type of microbe filled a special niche and played a different role in the nutrient cycle.

Microbes which were potential as bio-fertilizers were often found in rhizosphere. This is seen from the identification results. Several microbes like Azospirillum, Azotobacter, Pseudomonas, Aspergillus, and Streptomyces are potential to become bio-fertilizers or bio-controls. It is possible, because rhizosphere is rich with biological activity as microbes feed on the carbon compounds exuded by root, while organic and inorganic materials released by the plants into the areas (in the form of exudates), will be useful for life continuity of soil microbes (Setiadi, 1989)

\section{Bacteria}

Bacteria are the most dominant microorganisms in the soil. They may, perhaps, cover half of the biomass in the soil. Like Table 3., all samples, which were analyzed, contained bacteria of different population number. In acid soil type with low to moderate nutrient content, bacteria population spread unevenly. The result of identification of 11 soil types in 16 rhizosphere locations produced 20 genus (including 10 species). Azospirillum sp., Bacillus sp., Pseudomonas sp., Rhizobium sp., Thiobacillus sp., and Spaerotillus natans dominated the area. These bacteria are generally found in the soil regardless of the soil condition (Rao, 1994). In the identification results of soil sample number four and fifteen, a bacterium rarely found in the soil was identified, i.e. Escherichia coli. Rao proposed (1994) that $E$. coli was rarely found in the soil, except as a contaminant or a waste. This happens in the land of Wamena owing to the fact that natives live a very simple life. It is probable that they empty the bowels anywhere.

Bacteria can be found in any type of soil but their population is varied because of the influence of soil texture and organic substrate in the soil. Bacteria's ability to survive in favorable ecosystem is due to their character to form spores which have thick strong sheathes to make it easier for them to survive in a savage environment. Bacteria can also stand extreme climate condition although temperature, humidity, $\mathrm{pH}$, agriculture practice, fertilizers, pesticide, and the addition of organic matter can influence their population (Rao, 1994).

\section{Fungi}

The number of fungi in the soil is fewer than those of bacteria. All fungi have mycelium thread, which are organized from individual hypha. So, a fungi colony can dominate all soil types (RAO, 1994).

Fungi identification results of 11 soil types from 16 sites at WBiG produced nine genus, including one species (Aspergillus niger) which dominated several places at WBiG. This species is a fungi colony which can be found in many soil types because it has saprophytic character whose spores can be so easily distributed by air that genus can be present everywhere (in the fields, in the prairie, in the forest soil and in the degraded land, such as an ex-gold mine). 


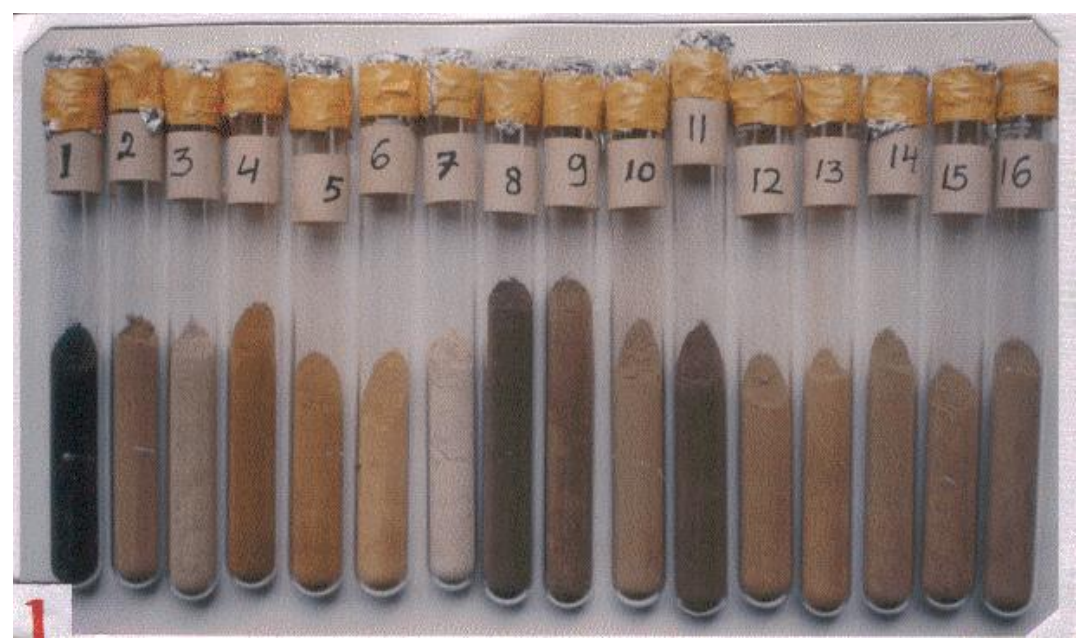

Figure 1. Soil color from 11 sites at Wamena Biological Garden.
Species domination is also determined by agriculture activities including crop plantation (practiced in Wamena) and the use of chemical fertilizers or pesticides (not practiced in Wamena). So, it can be said that fungi is one of the most important microbes in the soil ecosystem dynamics, because they function in the decomposition, mineralization and organize the migration of soil elements to plant root (Christensen, 1984 cit Suharna, 1999).

The results of fungi population count have the same total average (no obvious difference) (Table 4.). Thus, although a fungi colony is microbes which is more resistant to soil acidity, their live hood still depends on the availability of organic materials (Soepardi, 1978) and is much influenced by climate, especially soil moisture content (Sutejo et al., 1991).

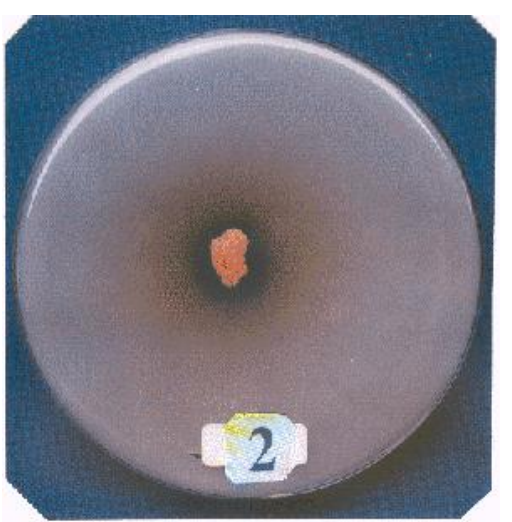

Figure 2. One of bacteria type (holozone of phosphate solubilizing bacteria).

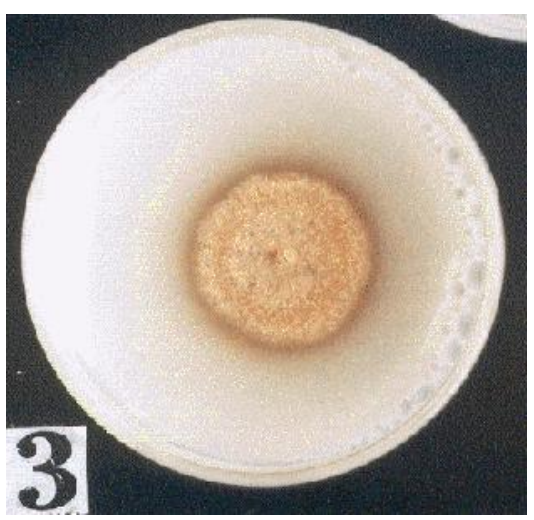

Figure 3. One of fungi type (holozone of phosphate solubilizing fungi).

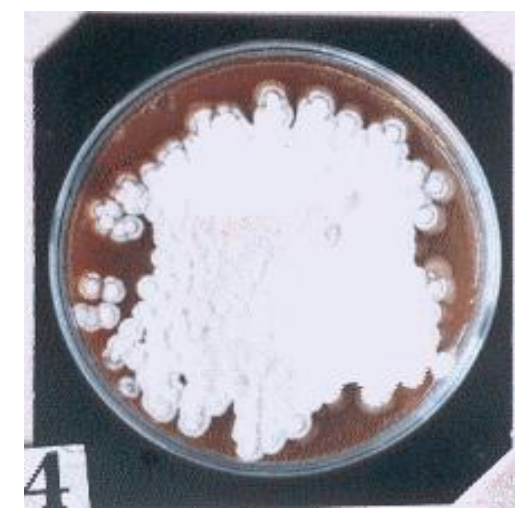

Figure 4. The one of actinomycetes type

Table 3. Identification and Population of soil bacteria from 16 sites at Wamena Biological Garden.

\begin{tabular}{|c|c|c|c|c|c|c|c|c|c|c|c|c|c|c|c|c|}
\hline \multirow[b]{2}{*}{ Microbes identified from soil } & \multicolumn{16}{|c|}{ The number of soil samples } \\
\hline & $\begin{array}{l}1 \\
\text { The }\end{array}$ & $\begin{array}{c}2 \\
\text { num }\end{array}$ & $\begin{array}{l}3 \\
\text { er of }\end{array}$ & $\begin{array}{c}4 \\
\text { pacte }\end{array}$ & $\begin{array}{l}5 \\
a(c\end{array}$ & $\begin{array}{l}6 \\
6\end{array}$ & $\begin{array}{l}7 \\
\text { soil) }\end{array}$ & 8 & 9 & 10 & 11 & 12 & 13 & 14 & 15 & 16 \\
\hline $\begin{array}{l}\text { Azospirillum sp. } \\
\text { Azotobacter chrococcum }\end{array}$ & $2+$ & $2+$ & $\begin{array}{l}2+ \\
2+\end{array}$ & $2+$ & $2+$ & $2+$ & $2+$ & $2+$ & $2+$ & $2+$ & $2+$ & $\begin{array}{l}2+ \\
1+\end{array}$ & $\begin{array}{l}2+ \\
1+\end{array}$ & $\begin{array}{l}2+ \\
1+\end{array}$ & $2+$ & $2+$ \\
\hline $\begin{array}{l}\text { A. paspalii } \\
\text { Acinetobacter sp. }\end{array}$ & $2+$ & & $2+$ & & & $3+$ & & $1+$ & & $2+$ & & $1+$ & $1+$ & $3+$ & $1+$ & \\
\hline $\begin{array}{l}\text { Bacillus sp. } \\
\text { B.panthothenticus }\end{array}$ & $3+$ & $3+$ & $2+$ & $\begin{array}{l}3+ \\
3+\end{array}$ & $3+$ & $3+$ & $3+$ & $3+$ & $3+$ & $\begin{array}{l}2+ \\
2+\end{array}$ & $\begin{array}{l}3+ \\
3+\end{array}$ & $3+$ & $3+$ & $3+$ & $3+$ & $3+$ \\
\hline Citrobactersp. & $3+$ & & & & $2+$ & $2+$ & & & & & & $3+$ & & & $1+$ & \\
\hline $\begin{array}{l}\text { Chromobacterium violaceum } \\
\text { C.lividum }\end{array}$ & $3+$ & & & $\begin{array}{l}2+ \\
2+\end{array}$ & & $1+$ & $1+$ & & & & $3+$ & $2+$ & & & $1+$ & \\
\hline Escherichia coli & & & & $1+$ & & & & & & & & & & & $1+$ & \\
\hline $\begin{array}{l}\text { Flavobacterium sp. } \\
\text { F. breve }\end{array}$ & $1+$ & & $1+$ & & $2+$ & & & & & & $1+$ & & & & & \\
\hline $\begin{array}{l}\text { Klebsiella sp. } \\
\text { K.aerogenes }\end{array}$ & & & & $\begin{array}{l}1+ \\
1+\end{array}$ & & & & $3+$ & $2+$ & & $2+$ & & & & $1+$ & \\
\hline $\begin{array}{l}\text { Nitrosomonas sp. } \\
\text { Pseudomonas sp. }\end{array}$ & $3+$ & $1+$ & & & $2+$ & $\begin{array}{l}1+ \\
3+\end{array}$ & & $3+$ & $1+$ & & $3+$ & & & & $3+$ & $1+$ \\
\hline Rhizospbium sp. & $2+$ & $2+$ & $2+$ & $2+$ & $2+$ & $2+$ & $2+$ & $2+$ & $2+$ & $2+$ & $2+$ & $2+$ & $2+$ & $2+$ & $2+$ & $2+$ \\
\hline Spaerotillus natans & $2+$ & $3+$ & $2+$ & & $2+$ & $2+$ & $1+$ & $3+$ & + & $3+$ & $3+$ & $1+$ & & $3+$ & & $1+$ \\
\hline Staphylococcus epidermidis & $2+$ & $1+$ & $3+$ & $1+$ & & $2+$ & & $3+$ & & $1+$ & $3+$ & $1+$ & & $1+$ & $1+$ & $1+$ \\
\hline Thiobacillus sp. & $2+$ & $1+$ & $1+$ & $3+$ & $1+$ & $1+$ & $1+$ & $1+$ & $1+$ & $2+$ & $2+$ & $1+$ & $2+$ & $1+$ & $1+$ & $1+$ \\
\hline$\sum$ all bacteria type & 11 & 9 & 7 & 11 & 8 & 12 & 6 & 9 & 7 & 8 & 11 & 10 & 6 & 8 & 12 & 7 \\
\hline
\end{tabular}

Annotation: $1+=$ low $\left(10^{4}-10^{5}\right), 2+=$ moderate $\left(10^{6}\right)$, $3+=$ high $\left(10^{7}-10^{8}\right)$. The vegetation of soil sample No.1 to No.11, same as Table 1 . The vegetation of soil sample No.12 to No 16: Imperata cylindrica, Imperata cylindrica, Ipomoea batatas, Castanopsis accuminattisima and Castanopsis accuminattisima. 
Table 4. Identification and population of fungi from 16 sites at Wamena Biological Garden.

\begin{tabular}{lllc}
\hline $\begin{array}{l}\text { Soil } \\
\text { samples }\end{array}$ & Vegetation & Species & Pop. \\
\hline 1 & Imperata cylindrica & Aspergillus niger & + \\
2 & Imperata cylindrica & Bisporomyces sp.. & + \\
3 & Imperata cylindrica & Monilia sp. & + \\
4 & Imperata cylindrica & Aspergillus niger & + \\
5 & Imperata cylindrica & Aspergillus niger & + \\
6 & Imperata cylindrica & Cephalospharium sp. & + \\
7 & Imperata cylindrica & Aspergillus niger & + \\
8 & Pittosporum ramiflorum & Aspergillus niger & + \\
9 & Vaccinium varingiaefolium & Aspergillus niger & + \\
10 & Castanopsis accuminattisima & Verticillum sp. & + \\
11 & Grevillea papuana & Gliocladium sp. & + \\
12 & Imperata cylindrica & Penicillium sp. & + \\
13 & Imperata cylindrica & Penicillium type A & + \\
14 & Ipomoea batatas & Penicillium type B & + \\
15 & Castanopsis accuminattisima. & Nelicocephalum sp. & + \\
16 & Castanopsis accuminattisima. & Cuninghamelle sp. & + \\
\hline
\end{tabular}

Table 5. Identification and population of actinomycetes from 16 sites at Wamena Biological Garden.

\begin{tabular}{lllc}
\hline $\begin{array}{l}\text { Soil } \\
\text { samples }\end{array}$ & Vegetation & Genus & Pop. \\
\hline 1 & Imperata cylindrica & Streptomyces & + \\
2 & Imperata cylindrica & Streptomyces & + \\
3 & Imperata cylindrica & Streptosporangium & + \\
4 & Imperata cylindrica & Streptomyces & + \\
5 & Imperata cylindrica & Nocardia & + \\
6 & Imperata cylindrica & Nocardia & + \\
7 & Imperata cylindrica & Streptomyces & + \\
8 & Pittosporum ramiflorum & Micromonospora & + \\
9 & Vaccinium varingiaefolium & Streptomyces & + \\
10 & Castanopsis accuminattisima & Streptomyces & + \\
11 & Grevillea papuana & Micromonospora & + \\
12 & Imperata cylindrica & Thermoactinomyces & + \\
13 & Imperata cylindrica & Streptomyces & + \\
14 & Ipomoea batatas & Streptomyces & + \\
15 & Castanopsis accuminattisima. & Thermomonospora & + \\
16 & Castanopsis accuminattisima. & Mycobacterium & + \\
\hline
\end{tabular}

In the acid soil area, dominated by Myristica cylindrica plants, eight fungi isolates were found and were dominated by $A$. niger. That species and other genus like Cuninghamella and Penicillium have a wide distribution, especially in the tropic and subtropics areas (Domsch and Gams, 1980). Then Sutedja (1991) stated that even though fungi were resistant to soil acidity, they were not resistant to drought and poor nutrition in the soil. It was the same with WBiG soil condition. The soil is so acid with low nutrients content that the number of fungi found was fewer than those of other microbes like bacteria Rao (1994) said that all environment factors which influenced bacteria and actinomycetes migration also influenced the migration of fungi in the soil.

\section{Actinomycetes}

Actinomycetes (order Actinomycetales) are a group of prokaryotic organisms belonging to gram-positive bacteria. Many of them show a branched filamentous growth, and generally form spores and some actinomycetes even form sporangia and zoospores. It mainly inhibits the soil and plays an important ecological role in recycling substances in the natural world (Miyadoh, 2003). Identification produced 6 genus from 16 soil samples, i.e. Mycobacterium, Nocardia, Micromonospora, Thermoactinomyces Streptosporangium, Actinomycetes, Thermonospora, and Streptomyces (Table 5. and 6.). Considering actinomycetes in the soil was quite plentiful, it was surprising that it was lack of the number of genus varieties. It is possible that the WBiG's soil ecosystem is not good enough for actinomycetes resulting from acid $\mathrm{pH}$ and low soil nutrient. Most actinomycetes are not tolerant to soil acidity.

The population of actinomycetes will decrease at $\mathrm{pH} 5.0$ (the suitable range is 6.5 to 8.0 ). Another factor is the method of taking the sample. It turned that the soil sample for identification was different from the soil sample for bacteria and fungi identification (0-15 $\mathrm{cm}$ depth). According to RAO (1994), the deeper the soil, the higher was the percentage of actinomycetes in the total microbes population. The increase of the discomposed organic matter would also increase the number of actinomycetes.

The identified actinomycetes were common genus, for example Streptomyces (almost 70\%), Nocardia and Micromonospora (Table 5a), while Streptomyces genus was often found in the heap of garbage with the temperatures of $55^{\circ} \mathrm{C}$ to $65^{\circ} \mathrm{C}$. Streptomyces species are very common in soil and responsible for the decomposition and degradation of natural and synthetic organic. Anonymous (2000) cit Sembiring (2003), note the genus of Streptomyces accommodates an unusually high degree of natural diversity with more than 500 validly described species. Nevertheless, a steady flow of new Streptomyces species are being described to accommodate either organisms isolated from diverse habitat.

Table 6. Representative characteristics of actinomycetes.

\begin{tabular}{|c|c|c|c|c|c|c|}
\hline \multirow{2}{*}{ Genus } & \multirow{2}{*}{ Isolates No. } & \multicolumn{5}{|c|}{ Morphology } \\
\hline & & Vegetative cell & Aerial mycelium & Sporangium & Spore & Motility \\
\hline Family Corybacteriaceae & & & & & & \\
\hline Mycobacterium & 16 & rod & - & - & - & - \\
\hline $\begin{array}{l}\text { Nocardia } \\
\text { Family Micromonosporaceae }\end{array}$ & 5 and 6 & mycelia, fr & + & - & long & - \\
\hline $\begin{array}{l}\text { Micromonospora } \\
\text { Family Streptosporangiaceae }\end{array}$ & 8 and 11 & mycelia & - & - & & - \\
\hline $\begin{array}{l}\text { Streptosporangium } \\
\text { Family Thermomonosporaceae }\end{array}$ & 3 & mycelia & + & + & multi & - \\
\hline $\begin{array}{l}\text { Thermomonospora } \\
\text { Family Streptomycetaceae }\end{array}$ & 15 & mycelia & + & - & 1 & - \\
\hline $\begin{array}{l}\text { Streptomyces } \\
\text { Others }\end{array}$ & $1,2,4,7,9,10,13,14$ & mycelia & + & - & long & - \\
\hline Thermoactinomyces & 12 & mycelia & + & - & 1 & - \\
\hline
\end{tabular}




\section{CONCLUSIONS}

The result of isolation, identification, and population soil microbes in rhizosphere from 16 samples at WBiG showed that 20 isolates of bacteria (Acinetobacter sp., Azospirillum sp., Azotobacter paspalii, A. chrococcum, Bacillus sp., and Bacillus panthothenticus Chromobacterium lividum, C. violaceum, Citrobacter sp., Escherichia coli, Flavobacterium sp., Flavobacterium breve, Klebsiella sp., K. aerogenes, Nitrosomonas sp., Pseudomonas sp., Rhizobium sp., Spaerotillus natans, Stapilococcus epidermidis, and Thiobacillus sp.); nine isolates of fungi (Aspergillus niger, Bisporomyces sp., Cephalospharium sp., Cuninghamella sp., Giocladium sp., Monilia sp., Nelicocephalum sp., Penicillium sp., and Verticillum sp.); and seven isolates of actinomycetes (Micromonospora, Mycobacterium, Nocardia, Streptomyces, Streptosporangium, Thermomonospora, and Thermoactinomyces). The population of Azospirillum (10 $\left.10^{7}\right)$, Bacillus $\left(10^{8}-10^{9}\right)$, Rhizobium $\left(10^{6-} 10^{7}\right)$, Thiobacillus $\left(10^{4}-10^{7}\right)$, Aspergillus niger $\left(10^{4}-10^{5}\right)$, and Streptomyces $\left(10^{4}-10^{5}\right)$ were founded all of soil samples.

\section{REFERENCES}

Charmichael, J.W., W.B. Kendrick, I.L. Conners, and L. Sigler. 1980. Genera of Hyphomycetes. Edmonton, Alberta: The University of Alberta Press.

Domsch, K.H. and W. Gams. 1980. Compedium of Soil Fungi. Vol. 1. London: Academic Press.

Ellis, M.B. 1993. Dematiaceous hyphomycetes. Surrey-London: IMI, Bakeham Lane, Egham, Surrey TW20 9TY, UK.
Gunarto, I., 2000. Mikroba rhizosfer: potensi dan manfaatnya. Jurnal Litbang Pertanian 19 (2): 1-20.

Jha, D.K., G.D. Sharma, and R.R Mishara. 1992. Ecology of soil microflora and mycorrhizal symbionts. Biology Fertility Soils 12: 272-278.

Krieg, N.R. and J.G. Holt.1984. Bergey's Manual of Systematic Bacteriology. Vol.1. Baltimore: Williams and Wilkins.

Lestari, Y, 2003. The potential of tropical streptomyces as source of new antibacterial compounds. Workshop on Diversity of Actinomycetes for Natural Conservation and Human Welfare, Bidang Mikrobiologi, Puslit Biologi, LIPI, Bogor, Indonesia, 1 April 2003.

Miyadoh, S. 2003. Identification Procedure for Bacteria and Actinomycetes. Diktat Training. Bogor: JICA kerjasama dengan Bidang Mikrobiologi, Puslit Biologi, LIPI

Rao, N.S. 1994. Mikroorganism Tanah dan Pertumbuhan Tanaman. Edisi kedua. Jakarta: Penerbit Universitas Indonesia.

Ravina, M.D., M.J. Acea, T. Carballas. 1992. Seasonal fluctuations in micobial populations and available nutrients in forest soil. Biology Fertility Soils 16: 198-204.

Sembiring, L. 2003. Streptomyces diversity associated with the rhizozphere of tropical legume, Paraserianthes falcataria (L.) Nielsen. Workshop on Diversity of Actinomycetes for Natural Conservation and Human Welfare, Bidang Mikrobiologi, Puslit Biologi, LIPI, Bogor, Indonesia, 1 April 2003.

Setiadi. Y. 1989. Pemanfaatan Mikroorganism dalam Kehutanan. Bogor: PAU Bioteknologi IPB.

Soepardi, G.1978. Sifat dan Ciri Tanah 2. Bogor: Fakultas Pertanian IPB

Suharna, N. 1999. Pengaruh perendaman di dalam air sebelum pemindahan terhadap pemulihan biak-biak Monascus spp, yang mengering. Jurnal Mikrobiologi Tropika 2 (2): 74-80.

Sutedja, M.M., A.G. Kartasapoetra, dan R.D.S. Sastroatmodjo. 1991. Mikrobiologi Tanah. Bandung: Rineka Cipta.

Thompson, J.P. 1989. Counting viable Azotobacter chroococcum in vertisols. Plant and Soil 117: 9-16.

Widawati, S and Suliasih 2001. The population of nitrogen fixing bacteria and phosphate solubilizing bacteria in the rhizosphere from Gunung Halimun National Park. Edisi khusus Biodiversitas Taman Nasional Gunung Halimun. Berita Biologi 5 (6): 691-695. 